\title{
The effect of the OSGIPE learning model based on the Indonesian National Qualification Framework on soft skills of Vocational high school technology Students
}

\author{
Julaga Situmorang*, Siman, Yuniarto Mudjisusatyo
}

*Department of Mechanical Engineering Education, State University of Medan, Jalan Willem Iskandar Pasar V, Medan 20221. Indonesia

Received: 02 Nov 2020; Received in revised form: 25 Nov 2020; Accepted: 01 Dec 2020; Available online: 22 Dec 2020

(C2020 The Author(s). Published by Infogain Publication. This is an open access article under the CC BY license

(https://creativecommons.org/licenses/by/4.0/).

\begin{abstract}
This research is a package that was carried out in a period of 3 years to develop a learning model based on the framework of Indonesia's national qualifications in an effort to improve students vocational high school soft skills. The first year conducted two years ago, a draft learning model was found, namely the OSGIPE model. In the second year, a formative evaluation was carried out on the OSGIPE model through one on one, small group, and limited field trials. There was a significant increase in students' soft skills amounting to $23.05 \%$. In the third year which is this year, a summative evaluation through wide field trials it have been carried out and still show that there is a significant increase in students' soft skills amounting to $23.44 \%$. It means that the OSGIPE model was feasible and effectively used to improve the soft skills of vocational high school technology students. So, the OSGIPE model can be used as an operational product concistently.
\end{abstract}

Keywords-OSGIPE instruction model, Soft Skills.

\section{INTRODUCTION}

Conceptually, competency-based curricula can be recognized as one of the means for implementing teaching and learning processes in the classroom to provide and broaden students' insights about knowledge, skills and other basic values in the hope that they can be reflected in the habits of thinking and acting. However, students have a very strong dependence on how they are treated by educators. That is, the success of students / students mastering competencies (learning outcomes) with regard to how lecturers / teachers practice learning systems in the implementation of learning.

Graduates' competencies for all educational institutions are related to hard skills and soft skills. In this regard, in general, education today is more about the development of hard skills $(90 \%)$ than the development of soft skills that are only $10 \%$ (Santoso, 2008). In fact, the results of research in Europe show that a person's success in the business world is $80 \%$ determined by his soft skillsand only $20 \%$ is determined by his hard skills(Wahidi in Santoso, 2008). This means that they prioritize soft skills rather than hard skills for graduates of educational institutions. The survey findings are in line with the opinion of Bergh, et al. (2006) which states that the human resources (HR) that will be able to exist in the 21 st century are those who have soft skills strong, in the form of the ability to think creatively, productively, make decisions, solve problems, learn how to learn, collaborate, and selfmanagement.

Workers often complain that workers from educational institutions who do not have good soft skills generally cannot stand the world of work, are not honest, get bored quickly, cannot work together, and cannot communicate verbally or write good reports (Irma, 2007). Therefore, various survey results also show that in recruiting workers almost all companies prioritize soft skills applicants'rather than their hard skills (Sutabri, 2007; Admin, 2008). 
Based on the description above, it can be concluded that reliable graduates from educational institutions expected by the business / industry are graduates who have high soft skills. If these reliable graduates are specified as graduates of Vocational High School (SMK), it means that the teaching staff (teachers) in Vocational Schools are required to first understand and have soft skills as expected by the business / industry to then form and / or develop them in their students through teaching and learning strategies. The logical consequence is that all Educational Teaching Institutions (LPTKs), including the UNIMED Faculty of Engineering's Mechanical Engineering Education Study Program, which will produce prospective teaching staff at Vocational Schools must also be able to form and develop these soft skills to their students as long as they attend college on campus. For this reason, the need for teachers / lecturers to design learning that can shape and develop soft skills that are clear and systematic, through needs analysis and developed by accommodating the demands of various stakeholders, and getting full support and commitment from all teaching staff (lecturers / teachers) in their implementation.

The implementation of the competency-based curriculum has been started in Vocational Schools since the 2006 school year. However, based on the results of the questionnaire given to students about the achievements of the soft skills designed in the learning implementation plan it turns out that it has not been in line with the target. Based on the survey of the practical learning process there were several problems. First, most students do not have the willingness to do the best and the standard or prioritize perfection, there is a tendency to just fulfill the task. Second, lack of systematic, well-coordinated work habits that reflect efficient and effective work. Third, lack of work independence, there is a tendency towards dependence on friends and teachers so that there are often process errors or products. Fourth, lack of initiative or creative ideas when encountering problems in the process or product, so the results are not optimal (Sudjimat, 2010).

These problems are due to the learning pattern so far emphasizing the mastery of hard skills and giving less portion to the efforts to developsoft skills so that they are side by side with hard skills.

This is thought to be caused by the learning strategies implemented not relevant to the characteristics of the field of study and the characteristics of students, as stated by Reigeluth (2009) that results that are effective, efficient and interesting are determined by the suitability of learning strategies with the characteristics of the study area and participants. Effective learning strategies are closely related to learning models. Kauchak and Eggen (2012) suggest that learning strategies are wrapped by learning models. Therefore, the assessment of learning strategies requires an assessment of the learning model. That is why the focus of the problems in this study were examined from the aspect of the learning model. The field of study or field of expertise in this study is limited to the field of design and construction, namely the design of metal splicing concentration machine elements.

The main problem in conceptual learning of vocational technology competencies is how to relevance learning outcomes with the Indonesian National Qualifications Frameworkcontained in the planning and readiness of teachers to managetheir learning in order to achieve the desired competencies of students, effectively, efficiently, and attractively, especially in field of welding technology. Achievement of learning outcomes is determined by the learning model applied. Therefore, the focus of the problem in this study is the development of an learning model based on Indonesian's national qualifications frameworkthat can improve students' soft skills.

In this study, the formulation of theproblem is: How is the appropriateness and effectiveness of thelearning model based on Indonesian's national qualification framework (KKNI) developed in order to improve students' soft skills?

\section{LITERATURE REVIEW}

Competence is basic knowledge, skills, and values reflected in the habit of thinking and acting. (Ministry of National Education, 2002). According to Burke (1995) "being able to perform whole work roles, to the standards of expected employment in a real working environment". From this definition, there are three competency criteria: a) able to carry out the overall tasks of the employee, rather than having specific skills or work tasks; b) in accordance with the standards expected in the work; c) in a real work environment that puts pressure on and relates to all work and the actual variations of work.

From the report SCANS (1991) identifies 5 (five) compotencies and 3 (three) basic parts of a person's skills and qualities to be able to handle work, namely: The five competencies: (a) resources: identifies, plans, and allocates resources; (b) interpersonal: works well with others; (c) information: acquires and uses information; (d) systems: understands complex interrelationships; (e) technology: works with a variety of technologies. The three-part foundation consists of:(a) basic skills: reads, writes, performs arithmetic and mathematical operations, 
listens, and speaks effectively; (b) thinking skills: thinks creatively, makes decisions, solves problems, visualizes, knows how to learn, and reasons; (c) personal qualities: display responsibilities, self-esteem, sociability, selfmanagement, integrity, and honesty.

Competence is a basic characteristic that consists of skills, knowledge and other personal attributes (soft skills) that are able to distinguish a person from performing and not performing. Spencer \& Spencer (1993) classifies competencies as basic characteristics, causal relationships and reference criteria as follows: 1) Basic characteristics are competence as part of an individual's personality and can predict behavior in situations and tasks, namely: a) motives as encouragement from self someone consistently to take an action; b) nature / character, namely physical characteristics and consistent responses to situations or certain information; c) self-concept, namely the values of attitudes or self-image possessed by individuals; d) knowledge, namely information that someone has for a particular field; and e) skills, namely the ability to carry out tasks physically or mentally. 2). Causal relationships are competencies that cause and predict behavior and performance. Motive competency, character / self-concept can predict behavioral actions that can ultimately predict performance results. 3). Reference criteria are the most critical competencies that can distinguish competencies with high or average performance. Thus vocational competence is a manifestation of one's abilities and skills to carry out overall vocational tasks in accordance with the expected standards in a real work environment.

Soft skills are broadly classified as a combination of personality traits, behaviors, and social attitudes that enable people to communicate effectively, collaborate, and manage conflict successfully (Snyder, 2020). People with good soft skills tend to have strong situational awareness and emotional intelligence to navigate difficult work environments while providing positive results. Another benefit of soft skills in the workplace is that it helps people adapt to changing circumstances. Able to communicate effectively during times of uncertainty or collaborate with others when solutions are not immediately found.

Soft skills are non-technical competencies that point to personality characteristics. This can be seen in a person's behavior, both when interacting in social situations, language skills, personal habits, or important traits to support optimistic behavior. Based on this, it can be said that soft skills are the strength of oneself to change or to overcome various work problems. Mastery soft skills of students'is the essence of competence that must be mastered and measured through performance during learning. Learning soft skills is seen as part of the effort to form a professional attitude. This attitude will influence behavior caring for quality, fast, right, and efficient, respecting time and reputation (Djoyonegoro, 1998). The attitude formation must be carried out from the beginning through the process of habituation to work that is developed and harmonized with learning needs.

Wagner (2008) emphasizes seven survival skills that have important values in this 21 st century era. When examined, skills theseare soft skills, namely: (1) critical thinking and problem solving, 2) collaboration through networks and leading with influence, (3) agile and able to adapt, 4) initiative and entrepreneurship, (5) effective communication both written and unwritten, (6) accessing and analyzing information; and (7) imagination and imagination. Thus, mastery of soft skills is important so that graduates are able to survive various work challenges.

In particular for welding technicians, work / industry managers are attracted to knowledgeable individuals with a mix of welding knowledge and skills and interpersonal skills. They become convinced that their new employee will represent a respectable company while doing a thorough job for the client. Here are five soft skills that welding companies / industries need for welding technicians (Nats, 2018), namely 1) problem-solving skills, 2) math skills, 3) organized skills, 4) communication skills, 5) mental and physical fitness.

Wikijob (2020), presents 10 soft skills needed by the world of work, namely 1) communication, 2) selfmotivation, 3) leadership, 4) responsibility, 5) teamwork, 6) problem management, 7) assertiveness, 8) the ability to work under pressure and time management, 9) flexibility, and 10) negotiation and conflict resolution.

From the description of the welding technician's soft skills and those given by Wagner above, it turns out that there are 10 types of soft skills identified by Wikijob. Therefore, a description of each type of soft skill will be presented below.

\section{1) Communication}

Communication is one of the most important soft skills. Communicators who and can adapt their tone and style to suit their audience, understand and act efficiently on orders, and explain complex issues to colleagues and clients.Equally important are verbal and non-verbal communication skills. Verbal communication skills are key to fostering collaborative, respectful, and, ultimately, productive relationships. It also relates to non-verbal communica-tion orwritten communication. A lot of business communication now takes place via email, so it's 
important to see good email etiquette and give orders clearly and concisely.

\section{2)Self-motivation}

Having a positive attitude and the initiative to work properly without supervision at all times are vital soft skills for every employee. It not only demonstrates reliability and commitment, but also demonstrates the ability to fit efficiently into the organizational structure without the need for constant supervision. A worker who is highly self-motivated will show a positive way of thinking, ambition, commitment and initiative.

\section{3)Leadership}

Leadership is a soft skill needed even though it does not directly manage other people. Those with strong leadership skills will have the ability to inspire others and lead teams to success. A person with good leadership skills will have a variety of skills that are useful in the workplace, including: a positive attitude and outlook, the ability to make quick and effective decisions, exemplary problem solving or conflict management skills, the ability to communicate effectively, a talent for motivating oneself and motivating others.

\section{4)Responsible}

Responsibility is a soft skill that is rarely discussed but highly valued. Colleagues who fail to take responsibility for their work are less productive and less successful overall. Someone who has a high level of responsibility will show the following attitudes: trustworthiness, discipline, motivation, awareness, andaccountable.

\section{5) Team work}

As with leadership skills, good teamwork involves a combination of other soft skills. Working in teams to achieve common goals requires intuition and interpersonal intelligence to know when to be a leader and when to listen. A good team player will show an attitude of responsiveness and accept the needs and responsibilities of others.

\section{6) Troubleshooting}

Problem solving skills not only require analytical, creative and critical skills, but also require a certain mindset. A person who can approach a problem with a cool, calm mind will often come up with a more efficient solution than those who cannot. Problem-solving skills can often rely on strong teamwork. Problems cannot always be solved alone. Therefore, knowing who can help come up with a solution, and how they can do it, can be a huge advantage.

7)Firmness
Assertiveness is characterized by the ability to make quick and effective decisions. Assertiveness combines several different abilities, such as: the ability to put things into perspective considering the choices, assessing all relevant information, anticipating all good and bad consequences. An assertive employee will take effective and judgmental action quickly, especially when under pressure. They are responsible for the consequences of their decisions and can adapt when mistakes are made.

\section{8)Ability to Work Under Pressure and Management Time}

Many jobs come with demanding deadlines and, at times, the stakes are high. Recruiters value candidates who display assertiveness, unwavering clear thinking skills, and the ability to isolate and put stress aside. Time management is closely related to the ability to work under pressure, as well as within tight deadlines. Employees who manage their time well can efficiently prioritize tasks and organize their diaries while adopting an attitude that allows them to take on new assignments and deadlines.

\section{9)Flexibility}

Flexibility is an important soft skill, because it shows the ability and willingness to accept new assignments and challenges calmly and without comment. Flexible employees are willing to help when needed, take on additional responsibilities, and can adapt quickly to changes in plans, display a willing and optimistic attitude, and are not affected by change.

\section{0)Negotiation and Conflict Resolution}

Negotiation and conflict resolution skills are one of the soft skills employers look for in potential leaders. Being a proficient negotiator is knowing how to be persuasive and exert influence, while sensitively looking for solutions that will benefit all parties. Likewise, conflict resolution depends on strong interpersonal skills and the ability to forge good relationships with colleagues and clients.

Soft skills can be observed through performance such as speaking ability that reflects ideas and information, or clearly explains a topic, is easy to understand topics that are unknown, able to interact and work cooperatively in groups. A person with high mastery of soft skills will reflect abilities that exceed the capacity as a workforce. This ability arises because the person concerned is independently able to move internal processes to continue learning, trying and finding something that benefits his work or for self-development. Thus soft skills are important to master because they are needed by someone to develop themselves in doing work.

Soft skills learning is packaged using an integration model with some ease of consideration. This means that 
the implementation of learning follows thelearning pattern hard skills implemented in accordance with the applicable curriculum implementation, does not require special funding and is more useful for strengthening hard skills.learning of softs skills Integratedis implemented with aapproach connected model, and nested models (Forgarty, 1991 \& Drake, 2007).

The integration of connected models emphasizes the relationship between soft skills and hard skills on every topic, concept, skill, and with the world of work today and in the future. Nested models are oriented towards achieving multiple skills and multiple targets. With this model, soft skills learning will be easily achieved because soft skills integratedare not forced. Every learning activity in it already has soft skills that are measured through learning targets.

\section{Learning Model Development.}

Richey (1986) defines the model as an illustration that results from the fact that it has an arrangement of a certain sequence. According to him the model can be used to organize knowledge from various sources then used as a stimulus to develop hypotheses and construct theories into concrete terms / conditions to apply them to practice or test theories.

Gustafson and Branch (2002) which emphasizes the practical function of a model that is a means to facilitate communication, or regular instructions (algorithms) that are prescriptive in order to make decisions, or planning instructions for management activities. Furthermore, it is said that a good model is a model that can help the user to understand what the overall process is fundamentally. The basis of a good model is the connection of several theories. Thus, it can be said that the benefits of the model for the user include: (1) explaining several aspects of human behavior and interaction, (2) integrating what is known through observation and research, (3) simplifying complex humanitarian processes, (4) guidelines to carry out activities.

In relation to learning, the learning model serves to direct educators to design learning that is used as a guide in the implementation of learning in order to achieve effective, efficient, attractive, and humanistic learning. Joice (2009) explains the learning model is a plan or a pattern that is used as a guide in planning classroom learning or learning in tutorials and for determining learning tools and directing us to design learning to help learning participants so that learning objectives are achieved.

Kaufman and English (2008) distinguish 3 (three) types of development models to determine which ones are appropriate and appropriate to use, namely: (1) inductive models, which depart from students' current behavioral experiences, then grouped, compared, developed and finally evaluated for revisions, (2) deductive models, beginning with determining general goals, determining criteria, finding links between existing / partner elements, collecting data, formulating specific objectives, developing and implementing, then evaluating and revising, (3) classic models, starting with some general requirements of objectives, program development, program implementation, then evaluated and revised.

The University Consortium for Instructional Development and Technology (UCIDT) presents a model that can be applied to the development of learning (Wittich \& Schuller (1999). The model includes 3 (three) stages: definition, development, and evaluation, divided into 9 (nine) with each of the 3 (three) steps and are interrelated with each other, namely:

Level I.Defining, including 1) Identifying the problem. In this first step what is done is identifying the problem, namely the gap between what is expected and the one that exists. More specifically, determine the conditions, what and what should be achieved by students, 2) The second step is the analysis of the situation, namely in an environment such as what learning is carried out, including students, learners (teachers), managers, and sources or materials learning, 3) The third step is organizing management, namely the executive leader who is responsible and carries out communication and other authorities.

Level II. Development, including 4) identification of objectives, as part of the development stage of learning begins with identifying specific learning objectives, if achieved, then the problem in the first step will be solved. In the formulation of goals must be stated: who are the participants or students (Audiences), behavior (Behavior) what can be done after the program is completed, under conditions (Condition) what they are formed, and level (Degree) of expertise achieved, 5) selection special methods or learning methods used to achieve goals, 6) constructing blueprints or prototypes, namely the components used, such as teaching preparation, exam materials, and specific guidelines and program evaluation.

Level III. Evaluate, copy 7) test the prototype. The evaluation phase begins by testing each component of the program. This initial trial was conducted on small samples and observations were held to see the presentation. Student comments are used as an assessment of what they are achieving, 8) analysis of results. The data collected in step seven determines the significance of the extent of the 
contribution given by each component to achieving goals, useful or not, 9) implementation / revision. Program improvement is done by looking at the achievement of certain goals, by reevaluating the contribution of learning components to achieving goals.

Regarding the product design model, there are five learning design models identified. The five models are (1) Kemp (1977), (2) Banathy (1978), (3) Calvano (1980), (4) Paul Harmon (1982) and (5) Dick \& Carey Models (2005). ) Of the five models, the learning design model from Dick, Carey \& Carey was chosen to be used in this study.

\section{RESEARCH METHODS}

This research using development research methods. A cycle of research and development is known as "the $R \&$ D cycle" (Borg \& Gall, 2007) combined with a design model learning from Dick, Carey and Carey (2009).In this study, survey methods were used through needs analysis, trial methods through procedures (a) expert review, (b) one-on-one trials, (c) small group trials, (d) limited scale field trials, and (e) wide-scale fieldtrials to produce operational products.Implementation of large group trials (field trials) using quasi-experimental methods with the design of "Pretest-Posttest Control Group Design".

\section{Population and Sample}

The population of this study were all students of the State Vocational School in the Field of Welding Technology in North Sumatra Province. The subjects of this study consisted of students from the State Vocational School of Welding Technology, consist of two cities and six regencies. This sampling uses a simple randomtechnique. For one-on-one trialsconsists of three students per school, the small group trialseight students per school, for limited scale field group trials200 students, and 400 students for wide-scale field trials.

Data collection techniques used in this study were questionnaire techniques and interview techniques, as well as documentation techniques to capture data on needs analysis activities, questionnaire techniques to capture data about riviuwer responses and students on expert validation activities and one-on-one trials (individual test) and smallgroup trials (small group test), and test techniques and observations on limited field testing activities as well as large-scale field trials.

The data analysis techniques used are (1) descriptive analysis to describe the data from the results of needs analysis and expert validation and one-on-one and small group trials. (2) t-test to find out the effectiveness of OSGIPE learning model for limited.

\section{RESEARCH RESULTS AND DISCUSSION}

\section{Research Results}

Based on the results of the analysis of the literature study, needs assessment,curriculum of vocational technology, there are six soft skills for welders, that is 1) communication skills, 2) team work and collaboration, 3) adabtability, 4) problem solving, 5) critical observation, and 6) work ethic skills.

Based on the results of learning analysis found the skills map (hard skills) for welders as shown below. 


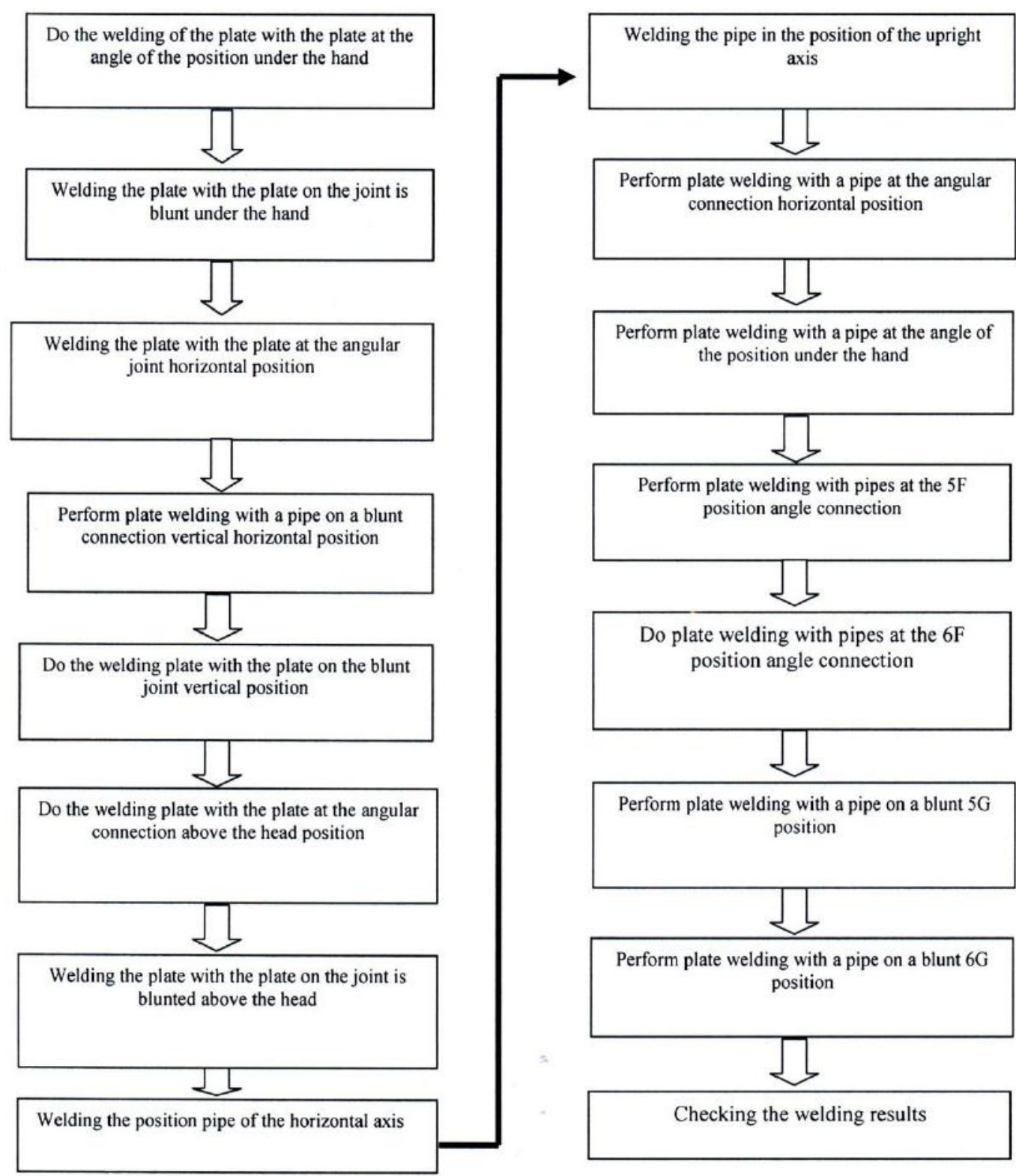

Fig.1: Welders Skills Map

Draft of hypothetical learning model based on the analysis of the results of the literature study and characteristics of competency and characteristics of the field of study which in the process raises the soft skills that have been identified based on the result of needs analysis can see as follows. 


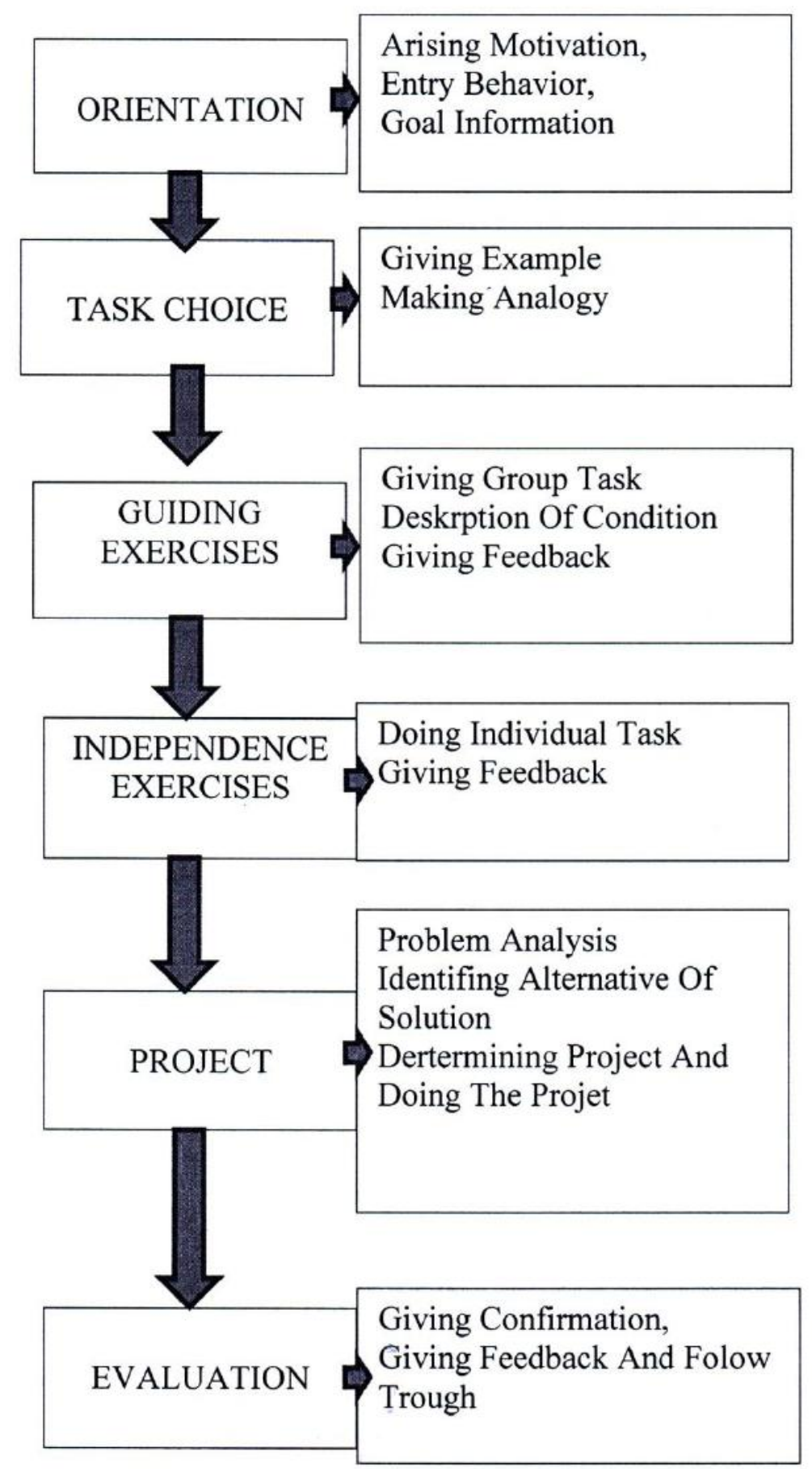

Picture. 2. Draft of Hypothetical Welding Learning Model Based on KKNI to Improve Soft Skills (OSGIPE Model).

Hypothetical Welding Learning Modelas shown in Figure 2 above is the initial model that will be continued through testing or through formative and summative evaluation as consistency of the application of the Dick, Carey and Carey (2005) models, consisting of six main steps , namely: 1) Orientation, including activities to build motivation, review the initial ability to explain objectives, 2) Select tasks, include activity description of conditions and analogies, 3) Guided exercises, including activities to provide examples, Group assignments, and Feedback, 4) 
Exercise Mandiri, covering individual task activities and feedback, 5) Projects, including problem analysis activities, alternative solutions, determining projects, completing projects, and 6) confirmation (testing), feedback, and follow-up.

The results of one-on-one trials showed that the feasibility of the OSGIPE learning model were found to be an average of 76.25, the results of small group trials amounted to 80.75, and limited field trials results amounted to 83.75 . When compared with the eligibility criteria, it is included in the good category.

The results of testing effectiveness of OSGIPE model related to limited field trials using pretest - posttest analysis showed that there was an increase in student soft skills as an effect of the implementation of the OSGIPE learning model (the average pretest is 59.03 and the average posttest is 86.69). This shows that the increase amounted to $23.05 \%$. Based on the results of the t-test, showed that the increase is significant at the $95 \%$ significance level. It means that OSGIPE model effective to improve soft skills of student.

The results of testing effectiveness of OSGIPE model related to wide field trials using pretest - posttest analysis showed that there was an increase in student soft skills as an effect of the implementation of the OSGIPE learning model (the average pretest is 58.57 and the average posttest is 86.70) amounted to $23.43 \%$ significantly at the $95 \%$ significance level. It means that OSGIPE model effective to improve soft skills of student consistently.

\section{Discussion}

The Learning Model of Welding Engineering Based on KKNI to improve soft skills as described earlier, is the initial product in this study which still requires further testing through formative evaluation and summative evaluation. According to the results of formative tests that have been done show that the OSGIPE learning model is effective for improving students' soft skills.

This is because the model has been built through theoretical studies of learning models that are thought to be able to foster personal competence, thinking skills, social competence, and vocational competence, as adapted from the learning models presented by Joyce, Weil, and Calhoun (2009), as well as Kauchak and Eggen (2012).

In the orientation phase, supported by the ARCS model from Keller (2010), namely the integration of learning motivation theory and research findings that are applied to the design of learning experiences.This is based on combining behavioristic, cognitive, and humanistic learning theories through his research.

In the task selection phase, it is supported by Gordon's synectict model (in Medsker and Holdsworth, 2001) and Gagne's (1985) condition of learning. According to Gordon, through the synectic model, creativity will be built. Gordon built this theory based on the cognitive learning theory and Gagne combined the theory of kognitivistik learning and the theory of conditioned response (Pavlop and Watson) and the theory of reinforcement (Skinner) in this case is the theory of behavioristic learning.

In the guided training phase, supported by the constructivist theory of Vygitsky and Bruner (1995), cooperative learning based on humanistic learning theory, and Skinner's theory of feedback (reinforcement) which is based on behavioristic learning theory.

In the independent training phase, it is supported by Scandura's (1983) structural learning theory which is based on cognitive learning theory and Skinner's theory of feedback (reinforcement) which is based on behavioristic learning theory.

In the project phase, supported by the constructivist theory of Vygitsky and Bruner (1995), cognitive inquiry (Pallesen, in Medsker and Holdsworth, 2001)

In the evaluation phase, it is supported by Skinner's theory of reinforcement, which is based on behavioristic learning theory.

The learning model is also based on the characteristics of the field of study / expertise and characteristics of students. Reigeluth (1996) suggests that if the learning method is adapted to the conditions of learning it will produce effective, efficient, and attractive results. This is also supported by Nadler (1988) explaining that a good model is a model that can help the user to understand what the process is fundamentally fundamental. Furthermore, it is said that the basis of a good model is the relation of several theories. Because the building of the learning model has been based on the interrelationship between several theories, it can be assumed that the model will be effective, efficient and attractive.

\section{CONCLUSIONS}

The OSGIPE learning model based on the Indonesian National Qualification Frame-Work feasible and effective to improve soft skills of vocational high school technology students consistently.Soft skills referred to here are:1) communication skills, 2) team work and collaboration, 3) adabtability, 4) problem solving, 5) 
critical observation, and 6) work ethic skills.The OSGIPE learning model has six main components:1) orientation, including motivation building activities, reviewing the initial ability to explain goals, 2) choosing assignments, including activity description conditions and giving analogies , 3) guided training, including activities to provide examples, group tasks, and giving feed-back, 4) independent training, includingcovering individual task activities and giving feedback, 5) projects, including problem analysis activities, alternative solutions, determining projects, and completing projects, and 6) evaluation includes confirmation activities, giving feedback, and follow-up.Improvement of students' soft skills amounted to $23.05 \%$ as a result of the implementation of the OSGIPE learning modelrelated to limited field trials and $23.44 \%$ related to wide field trials.

\section{REFERENCES}

[1] Admin. 2008. Importance of Soft Skills. http://infocomcareer.com. html, accessed May 15, 2017.

[2] Borg, WR, Gall, JP, and Gall, MD 2007. Educational Research.8. Pearson Edition. New York

[3] Bergh, et al. 2006. Medical Students Perceptions of their Development of Soft skills. Part II: the Development of Soft skills through Guiding and Growing. http://www.sofpj.co.za/index.php/safpj/article/viewfile/661/575. Accessed May 22, 2017.

[4] Burke, J. (1995). Competency based education and training. London: The Falmer Press.

[5] Dick, W., Carey, L., and Carey, JO, 2005. The systematic design of instruction. New York: Pearson

[6] Ministry of National Education. 2002. Development of competency-based curriculum syllabus. Jakarta: Center for Curriculum, Balitbang Depdiknas Depnakertrans. 2006.

[7] Drake, MS 2007. Creating standards-based integreted curriculum. California: Corwin Press

[8] Djoyonegoro, Wardiman. 1998. Development of human resources through Vocational School. Jakarta: Jayakarta Agung Offset.

[9] Gustafson, Kent L. and Branch, Robert M.2002. Survey of instruction development models, $4^{\text {years }}$. Ed. Syracuse, NY: Eric Clearing house.

[10] Forgarty, Robin. 1991. How to integrate the curricula. Illinois: IRI Publishing.

[11] Gagne, R.M. 1985. The condition of learning and theory of instruction ( $4^{\text {th }}$ ed.) Forth Worth, TX:Holt, Rinehart \& Winston.

[12] Irma, Yulaelawati.2007. Kcurricula have andlearning.Bandung: Raya Expert

[13] Joyce, B., Weil, M., Calhoun, E. 2009.Models of teaching. New Jerdey: Pearson

[14] Kaufman, R., English, FW 2008. Needs assessment: concept and application, 5th Ed. Educational Technology. New Jersey.
[15] Kauchak and Eggen. 2012. Strategy and models for teachers: teaching content and thingking skills. New York: Pearson

[16] Keller, J.M. 2010. Motivational desain for learning and performance. New York: Springer.

[17] Medsker, K.L. and Holsworth, K.M. 2001. Models and strategies for training design.Silver Spring: International Society for Performance Improvement.

[18] Napitupulu, E., Situmorang, J. and Mursid. 2014. The Instructional Model Development Based on Interactive Multimedia on Technical Mechanics Competence of Vocational High School Students of North Sumatera Province. TheInternational Journal of Education and Research. 2(8): 1-10.

[19] Nats.2018. https://www.nats.ca

[20] Reigeluth, Charles M. 2009. Instructional desain theoriesand models, vol.III. New York: Taylor and Francis.

[21] Richey, R. 1986. The Theoretical and Conceptual Base of Instructional Design.London: Kogan Page.

[22] Santoso, Slamet. 2008. Integrasi Soft Skill Mahasiswa di Perkuliahan: Langkah Lebih Pengembangan dan Pendekatan Pendidikan di PT. http:// slamet santos o.com.html, diakses, 10 Mei 2017.

[23] Scandura, J.M. 1983. Instructional strategies based on the structural theory. In C.M. Reigeluth (Ed.), Instructional design teories and models: An overview of their current status (213-246). Hillsdale, NJ: Lawrence Erlbaum Associates.

[24] Situmorang, J. 2002. Pengembangan Model Pembelajaran Keterampilan Psikomotorik Untuk Pelatihan BLK/KLK Depnaker Dalam Upaya Peningkatan Kualitas Tenaga Kerja. Laporan Penelitian Hibah Bersaing IX/2 Perguruan Tinggi. Tahun Anggran 2003. pp.53-54 (Tidak dipublikasikan).Unimed, Medan.

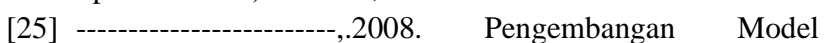
Pembelajaran Berbasis Komputer Untuk Meningktkan Kompetensi Kejuruan Siswa di SMK Kota Medan Sumatera utara. Laporan penelitianTahun I. Medan: Lemlit Unimed

[26] -----------------.2009. Pengembangan Model Pembelajaran Berbasis Komputer Untuk Meningktkan Kompetensi Kejuruan Siswa di SMK Kota Medan Sumatera utara. Laporan penelitianTahun II. Medan: Lemlit Unimed

[27] .............................2010. Pengembangan Model Pembelajaran Berbasis Komputer Untuk Meningkatkan Kompetensi Kejuruan Siswa di SMK Kota Medan Sumatera utara. Laporan penelitianTahun III. Medan: Lemlit Unimed

[28] ............................ .2011. Pengkajian Program Lembaga Kursus dan Pelatihan (LKP) dalam Menyelenggarakan Program Pendidikan Kecakapan Hidup(PKH) di sumatera utara. Jurnal Teknologi Pendidikan, Vol. 5 No. 1 April 2012, hal 31-51.

[29] ............................., .2014. Pengembangan Model Pembelajaran Pelatihan Berbasis Life Skill Pada 
Lembaga Kursus Dan Pelatihan Di Provinsi Sumatera Utara. Laporan penelitianTahun I. Medan: Lemlit Unimed

[30] ........................... .2015. Pengembangan Model Pembelajaran Pelatihan Berbasis Life Skill Pada Lembaga Kursus Dan Pelatihan Di Provinsi Sumatera Utara. Laporan penelitianTahun II. Medan: Lemlit Unimed

[31] ............................, .2016. Pengembangan Model Pembelajaran Pelatihan Berbasis Life Skill Pada Lembaga Kursus Dan Pelatihan Di Provinsi Sumatera Utara. Laporan penelitianTahun III. Medan: Lemlit Unimed.

[32] Snyder, K. 2020. https://www. omniagroup.ca

[33] Spencer, LM, \& Spencer, SM (1993). Competence work: Models for superior performance. New York: John Wiley \& Sons, Inc.

[34] Sujimat, Dwi A. 2008. Pengembangan Model Pendidikan Soft Skill Melalui Pembelajaran. Jurnal Teknologi Kejuruan, Vol. 33, No. 2, September 2010, hal 133-142

[35] Sutabri, Tata. 2007. Sarjana Komputer di Era Informasi. www.kabar - indonesia. com.html, diakses 13 Mei. 2017.

[36] Wagner,T.2008.The Global Achievement Gap. New York: Basic Books.

[37] Wikijob. 2020. https://www.wikijob.co.uk

[38] Wittich WA \& Schuller CF (1999). Instructional technology: Its nature and use. $10^{\text {th }} \mathrm{ed}$. New York: Harper \& Ro 